\title{
Sulfate Reduction of Rice Paddy, Foreshore, and Reservoir Soil
}

\author{
Kim, Min Jeong and Kyeong Ryang Park* \\ Department. of Biotechnology, Hannam University, Daejeon 305-811, Korea
}

Received January 25, 2010 / Accepted August 17, 2010

\begin{abstract}
Sulfate reduction rates (SRR) using ${ }^{35} \mathrm{SO}_{4}^{-2}$, sulfide producing rates (SPR) using gas chromatography, the number of sulfate reducing bacteria (SRB) using the most probable number (MPN) method, and soil components (moisture, ammonium, total nitrogen, total organic carbon, total carbon, total inorganic phosphorus, total phosphorus, and sulfate) using standard methods in the organic/conventional rice paddy soils, cleaned/polluted reservoir soils, and cleaned/polluted foreshore soils were studied with the change of seasons. The average SRR was more related to the number of SRB and soil components (especially nitrogen and phosphorus) than sulfate concentration. SRR was also recorded to be highest in October soil samples. However, SPR was higher in foreshore soils containing a high concentration sulfate than in fresh water soils, and it was also recorded to be higher in the polluted areas than in clean areas. From these results, we can conclude that the SRR and SPR of anaerobic environments were affected by the number of SRB, soil components and temperature.
\end{abstract}

Key words : Anaerobic soil, most probable number, soil components, sulfate reducing bacteria, sulfate reduction

\section{서 론}

혐기성 상태를 유지하는 물에 잠긴 토양의 유기물 분해는 매우 복잡하며 여러 미생물 군집이 관여하는 일련의 동조된 과정에 의해 일어난다[7]. 다양한 미생물에 의해 고분자 물질 이 단량체로 분해된 후, 분해된 단량체는 Clostridium, Lactobacillus, Acetobacter 속의 일차적인 발효세균에 의해 휘발 성 지방산, 알콜, 초산, 개미산, 수소, 이산화탄소 등으로 발효 된다. 그리고 이들에 의해 생성된 초산, 개미산, 수소, 이산화 탄소는 메탄생성세균에 의해 직접 메탄으로 전환하지만, 그 외의 발효 산물들은 이차적으로 발효균들의 대사활동으로 초 산이나 수소, 이산화탄소로 다시 전환된 후 메탄생성에 이용 된다.

그러나 질산염, 철, 망간, 황산 등의 전자수용체가 존재하면 유기물의 혐기성 분해과정이 달라진다. 질산염이 존재하면 탈 질(denitrification)과정으로 유기물이 분해되고, 철과 망간과 같은 금속이온이 존재하면 금속이온을 환원하며 에너지를 얻 고, 황산염이 존재하면 최종 전자수용체로 황산염을 이용하는 혐기성 세균인 황산염 환원세균(sulfate-reducing bacteria, $\mathrm{SRB})$ 에 의해 황화수소를 생성하며 에너지를 획득한다. 그리고 실제 이들 과정들이 메탄 생성보다 열역학적으로 우수하므로 이 전자수용체들이 존재하면 이들을 이용하는 방향으로 분해 가 진행된다. 하지만 일반적으로 혐기성 환경을 유지하는 물 에 잠긴 토양은 질산염의 농도가 매우 낮고, 철과 망간 등의

\section{*Corresponding author}

Tel : +82-42-629-8770, Fax : +82-42-629-8769

E-mail : krpark@hnu.kr
금속이온은 고체 상태나 낮은 농도로 존재하기 때문에 이 두 과정은 혐기성 환경의 미생물 활성에 크게 영향을 주지 못한 다[23]. 따라서 혐기환경에서 나타나는 가장 일반적인 탄소순 환 과정은 메탄생성(methanogenesis)과 황산염 환원 과정이 일어난다. 보통 담수에서는 황산염의 농도가 낮아 메탄생성이 주로 일어나고, 해양과 염습지는 적당량의 황산염이 함유되어 있기 때문에 유기물 분해의 $70 \%$ 까지 황산염 환원과정으로 진 행된다[10,22]. 이에 따라 해양의 황산염 환원 연구는 갯벌, 염 습지를 대상으로 그 연구가 비교적 많이 진행되고 있지만[1, 3], 황산염을 적게 함유하고 있는 담수 토양의 황산염 환원 연구는 거의 이루어 지지 않고 있다. 그러나 일부 연구 결과 담수도 해수만큼 황산염 환원이 많이 이루어지고 있는 것으로 확인되고 있다[1,6].

본 연구는 오염된 연못과 청정 연못, 오염된 갯벌과 청정 갯벌, 유기 농법 논과 일반 관행농법의 논토양을 채집하여 이 들 토양의 화학적 성분과 토양에 따른 황산염 환원률(sulfate reduction rate, SRR)과 황산염 환원균수, 황화수소 생성량을 측정하여 담수와 해수의 혐기 환경토양, 그리고 오염된 혐기 환경토양과 청정 혐기환경 토양에서의 황산염환원에 대한 상 관관계가 있는지를 전체적으로 조사하고자 하였다.

\section{재료 및 방법}

\section{토양 시료 및 사용배지}

토양 시료는 유기농의 경우 친환경농법으로 인증된 충청남 도 당진, 예산, 청양의 논에서, 관행농법(농약) 토양은 충북 청 원과 충남 당진의 논에서, 청정담수의 토양은 주변 환경이 산 
으로 둘러 싸여 오염원이 적은 것으로 판단되는 충북 옥천과 영동, 충남 청양의 저수지에서, 오염담수는 오래된 낚시터와 주변 환경이 식당이나 산업단지에 인접해 있어 오염에 노출된 것으로 판단되는 충북 옥천과 대전광역시에 위치한 저수지 토양을, 그리고 청정 갯벌은 충남 서산의 구도리 주변의 갯벌 토양을, 오염 갯벌은 전남 광양의 석유화학단지 주변의 갯벌 토양을 채취하여 사용하였다. 시료 채취 시기는 논토양의 경 우 벼의 생육에 따라 미생물 군집이 영향을 받으므로 모내기 직후인 6 월과 장마가 끝난 후인 8 월, 벼가 익어가는 10 월, 그리 고 추수 후인 11월에, 담수와 갯벌 토양은 6월, 8 월, 10 월, 12 월 총 4 회에 걸쳐 토양을 채취하였고, 혐기성 배양은 basal carbonate-yeast extract-trypticase (BCYT) 배지를 기본 배지로 사용 하여 실온에서 배양하였다[19].

\section{토양시료 채취}

유기농법, 관행농법, 청정담수, 오염담수, 청정해수, 오염해 수 총 6 가지 종류의 토양을 6 월, 8 월, 10 월과 11월(12월) 총 4 회에 걸쳐 채취하였다. 토양시료는 유기농과 농약, 청정, 오 염담수 그리고 청정, 오염 갯벌 별로 각각 3지점의 토양에서 각 지점 별로 각각 3 곳의 깊이 $10 \mathrm{~cm}$ 정도의 토양을 채취한 후, 이들을 동량씩 혼합하여 각 지점의 대표적인 시료로 사용 하였다. $4^{\circ} \mathrm{C}$ 로 유지하면서 운반된 토양은 황산염 환원균수, 황산염 환원율, 황화수소 생성량 그리고 기질 소모량 측정 실 험을 위해 모두 $4^{\circ} \mathrm{C}$ 에서 보관하며 실험하였다.

\section{토양성분 분석}

토양성분은 공정시험법에 의거해 분석하였다. 토양 내 수분 은 건토 중량법으로 건조기(FO-600M, Jeio tech, Korea)에서 $110^{\circ} \mathrm{C}$ 에서 24시간 건조한 후 무게를 측정하였고, 총 질소(total nitrogen, TN)는 Kjeldahl 법으로 측정하여 $0.001 \mathrm{~N} \mathrm{H}_{2} \mathrm{SO}_{4}$ 로 적정하였다. 그리고 시료 내 총 인산(total phosphorus, TP)은 과염소산 분석법을 이용하여 $470 \mathrm{~nm}$ 에서 분광기(Lambda EZ201, Perkinelmer, USA)로 비색측정을 하여 결정하였고, 총 탄소(total carbon; TC)와 총 유기탄소(toral organic carbon, $\mathrm{TOC})$ 는 $0.05 \mathrm{~g}$ 의 시료를 탄소 측정기(SSM-500A, Shimadzu, Japan)를 이용하여 측정하였다. 그리고 총 무기인(total inorganic phosphorus; TPi)은 $1 \mathrm{~g}$ 의 시료를 처리하여 1-amino-2-naphtol-4-sulfonic acid로 발색 시킨 후 $440 \mathrm{~nm}$ 에서 분광 기(Lambda EZ201, Perkinelmer, USA)로 측정하였고, 암모니 아(extractable ammonium; $\mathrm{NH}_{4}{ }^{+}$)는 토양 시료 $10 \mathrm{~g}$ 을 건토화 하여 침출액을 넣어 항온 배양기(SI 900R, Jeio Tech., Korea)에 서 추출하고, 여과한 후 $0.001 \mathrm{~N} \mathrm{H}_{2} \mathrm{SO}_{4}$ 로 적정하여 정량하였 으며, 황산염 $\left(\mathrm{SO}_{4}^{-2}\right)$ 은 $2.5 \mathrm{ml} 25 \%$ 질산과 $2 \mathrm{ml}$ acetic-phosphoric acid, $0.5 \mathrm{ml}$ 황산바륨 현탁액과 $0.2 \mathrm{~g}$ 염화바륨을 첨가 하여 $440 \mathrm{~nm}$ 에서 측정, 분석하였다.

\section{황산염환원 세균 수 조사}

토양시료 내에 기질로 초산과 젖산을 이용하는 황산염환원 세균의 수를 most probable numbers (MPN) 방법으로 실험한 후[2], 그 결과를 most probable numbers calculator (version4.04; United States Environmantal protection agency, Ohio) 프로 그램을 이용하여 산정하였다.

\section{황화수소 발생량 측정}

$1 \mathrm{~g}$ 의 토양을 $9 \mathrm{ml}$ 의 혐기성 BCYT 배지가 들어있는 혐기배 양 시험관(Bellco Glass Inc., Vineland, N.J.)에 넣고 고무마개 로 닫은 후, aluminum seals로 밀봉하였다. 이 시험관에 멸균 된 주사기를 이용하여 $20 \mathrm{mM}$ 의 초산과 젖산을 각각 주입하였 고, 모든 시험관에는 $2 \mathrm{mM}$ 의 황산나트륨을 환원제 및 황원으 로 첨가하였다. 이를 $30^{\circ} \mathrm{C}$ 의 항온 배양기에서 정치배양 하면 서, 매주 5주 동안 디지털 압력계(DPI 705; Druck)를 이용하여 압력을 측정하였고, GC-14B 유리 컬럼(Shimadzu)과 불꽃광검 출기(FPD)가 부착된 가스크로마토그래피(GC-14B, Shimadzu, Japan)를 이용하여 황화수소 생성량을 조사하였다. 이 때, 실 험조건은 운반가스로 질소를 사용하였으며 유속은 $13 \mathrm{psi}$ 로 하였고, 공기와 수소는 각각 $5 \mathrm{kgf} / \mathrm{cm}^{2}$ 로 조정하였다. 컬럼 오븐의 온도는 $100^{\circ} \mathrm{C}$, 시료 주입부는 $150^{\circ} \mathrm{C}$, 검출기는 $150^{\circ} \mathrm{C}$ 로 조정 하였고, 혐기시험관 내의 가스를 $25 \mu \mathrm{l}$ 씩 주입한 후 생성 하는 피크 면적 값을 표준 황화수소 가스를 이용한 표준곡선 을 이용하여 황화수소 생성량으로 환산하였다.

\section{황산염 환원율 측정}

$2.5 \mathrm{ml}$ 의 $10 \%$ 초산 아연이 들어있는 시험관을 장착한 시험 병에 토양시료 $1 \mathrm{~g}$ 과 $1 \mathrm{ml}$ 의 BCYT 배지를 질소가스 충진 하에 첨가한 후, $2 \mathrm{uCi}{ }^{35} \mathrm{~S}_{-} \mathrm{SO}_{4}{ }^{2}$ 를 주입하고 암소에서 2시간 배양하며 황산염을 환원시켰다. 그 후 주사기를 통해 혐기상 태의 $6 \mathrm{M}$ 염산 $8 \mathrm{ml}$ 과 $0.5 \mathrm{M}$ 염산에 용해된 $1 \mathrm{M}$ 염화크롬(II) $8 \mathrm{ml}$ 을 주입하고 48시간 동안 환원된 황산염을 포획한 후, trap 내에 포획된 방사성 동위원소와 시험병 내에 남아있는 환원되지 않은 ${ }^{35} \mathrm{SO}_{4}{ }^{2-}$ 동위원소 량을 액체섬광계수기(LS 6500, Beckman Coulter, Fullerton, CA)로 측정한 후[20], 황산 염 환원율을 조사하였다[8].

\section{결 과}

\section{토양 성분}

토양시료의 성분 분석 결과(Table 1), 수분함량은 유기농법 토양이 농약 토양보다, 그리고 갯벌 토양 보다 담수 토양에서 더 높게 나타났고, 각 토양의 수분 함량은 장마 후인 8월에 채취한 토양에서 가장 높게 나타났다. 그리고 계절이 겨울로 갈수록 전반적으로 수분 함량은 감소하였으나 청정 지역과 오염 지역 토양간의 수분 함량 차이는 나타나지 않았다. 
Table 1. Chemical compositions of soils used in this study

\begin{tabular}{|c|c|c|c|c|c|c|c|c|c|}
\hline $\begin{array}{l}\text { Field } \\
\text { station }\end{array}$ & $\begin{array}{l}\text { Sampling } \\
\text { month }\end{array}$ & $\begin{array}{c}\text { Moisture } \\
\text { content (\%) }\end{array}$ & $\begin{array}{c}\mathrm{NH}_{4}^{+} \\
(\mathrm{mg} / \mathrm{kg})\end{array}$ & $\begin{array}{c}\mathrm{TN} \\
(\mathrm{g} / \mathrm{kg})\end{array}$ & $\begin{array}{c}\mathrm{TP} \\
(\mathrm{g} / \mathrm{kg})\end{array}$ & $\begin{array}{c}\mathrm{TPi} \\
(\mathrm{mg} / \mathrm{kg})\end{array}$ & $\begin{array}{c}\text { TC } \\
(\mathrm{g} / \mathrm{kg})\end{array}$ & $\begin{array}{l}\text { TOC } \\
(\mathrm{g} / \mathrm{kg})\end{array}$ & $\begin{array}{c}\mathrm{SO}_{4}^{-2} \\
(\mathrm{mg} / \mathrm{kg})\end{array}$ \\
\hline \multirow{4}{*}{$\begin{array}{l}\text { Organic rice } \\
\text { paddy soil }\end{array}$} & June & 25.88 & 6.95 & 1.32 & 3.8 & 357.52 & 14.86 & 14.86 & 2.92 \\
\hline & August & 30.95 & 16.47 & 1.29 & 4.74 & 446.4 & 13.27 & 13.27 & 3.37 \\
\hline & October & 35.85 & 12.11 & 1.86 & 6.49 & 381.88 & 17.93 & 17.93 & 3.83 \\
\hline & November & 22.31 & 27.29 & 1.42 & 5.42 & 329.31 & 16.23 & 16.21 & 3.3 \\
\hline \multirow{4}{*}{$\begin{array}{l}\text { Conventional } \\
\text { rice paddy soil }\end{array}$} & June & 25.67 & 6.93 & 1.01 & 4.28 & 210.64 & 0.13 & 5.17 & 2.7 \\
\hline & August & 26.59 & 9.18 & 1.09 & 1.87 & 288.68 & 9.03 & 9.03 & 2.28 \\
\hline & October & 24.47 & 3.21 & 2.09 & 3.83 & 256.07 & 12.51 & 12.44 & 2.58 \\
\hline & November & 14.57 & 41.23 & 1.04 & 4.99 & 215.73 & 8.85 & 8.82 & 5.71 \\
\hline \multirow{4}{*}{$\begin{array}{l}\text { Cleaned } \\
\text { foreshore soil }\end{array}$} & June & 23.22 & 6.42 & 0.45 & 3.8 & 280.28 & 5.34 & 5.29 & 38.49 \\
\hline & August & 29.22 & 8.63 & 0.7 & 2.75 & 341.56 & 5.95 & 5.9 & 31.53 \\
\hline & October & 21.42 & 24.04 & 0.85 & 3.71 & 403.81 & 6.32 & 6.23 & 37.74 \\
\hline & December & 18.58 & 10.77 & 0.63 & 2.38 & 194.07 & 3.94 & 3.94 & 28.34 \\
\hline \multirow{4}{*}{$\begin{array}{l}\text { Polluted } \\
\text { foreshore soil }\end{array}$} & June & 27.64 & 1.48 & 0.73 & 5.9 & 357.52 & 12.82 & 10.09 & 49.55 \\
\hline & August & 27.69 & 5.91 & 1.06 & 3.31 & 300.44 & 13.69 & 11.25 & 34.87 \\
\hline & October & 16.17 & 20.57 & 1.17 & 2.78 & 210.96 & 14.57 & 12.45 & 48.19 \\
\hline & December & 11.10 & 8.07 & 0.43 & 4.32 & 343.43 & 11.21 & 9.25 & 31.44 \\
\hline \multirow{4}{*}{$\begin{array}{l}\text { Cleaned } \\
\text { reservoir soil }\end{array}$} & June & 17.17 & 6.74 & 0.22 & 1.85 & 111.6 & 13.74 & 13.74 & 1.55 \\
\hline & August & 38.84 & 7.72 & 1.79 & 2.22 & 177.88 & 23.36 & 23.36 & 2.52 \\
\hline & October & 25.59 & 26.96 & 1.81 & 3.75 & 64 & 18.57 & 14.25 & 1.64 \\
\hline & December & 16.21 & 11.99 & 0.43 & 4.63 & 357 & 10.04 & 10.21 & 0.63 \\
\hline \multirow{4}{*}{$\begin{array}{l}\text { Polluted } \\
\text { reservoir soil }\end{array}$} & June & 37.62 & 12.95 & 1.29 & 8.29 & 180.4 & 17.11 & 16.98 & 3.06 \\
\hline & August & 27.78 & 18.15 & 2.35 & 6.61 & 591.6 & 0.13 & 0.13 & 2.37 \\
\hline & October & 17.20 & 31.54 & 2.58 & 3.63 & 215.51 & 24.14 & 24.34 & 2.03 \\
\hline & December & 38.15 & 11.09 & 1.67 & 2.66 & 92.73 & 21.28 & 21.26 & 2.52 \\
\hline
\end{tabular}

$\mathrm{TN}$, total nitrogen; $\mathrm{TP}$, total phosphorus; $\mathrm{TPi}$, total inorganic phosphorus; $\mathrm{TC}$, total carbon; $\mathrm{TOC}$, total organic carbon.

총 탄소는 농약과 청정 갯벌 토양에서 낮은 함량을 나타내 고, 오염 지역 토양이 청정 지역 토양보다 비교적 높음을 알 수 있었으나, 수분함량의 경우처럼 계절의 변화에 따른 차이 는 볼 수 없었다. 그러나 대부분의 토양에서 10월에 채취한 토양의 총 탄소 함량이 높게 나타났다. 그리고 총 유기탄소도 총 탄소와 비슷하게 관행 농법과 청정 갯벌 토양에서 낮은 함량을 나타냈고, 계절과 오염에 따른 연관성은 뚜렷하게 구 분되지 않았다.

질소 성분인 암모니아의 함량은 오염 갯벌에서 비교적 높은 함량을 나타냈고, 계절적으로 논토양이 겨울로 진행 될수록 암모니아 성분이 축적되었고, 담수 토양과 갯벌 토양은 10 월 에 채취한 토양에서 가장 높은 함량을 나타냈다. 그리고 총 질소는 갯벌 토양보다는 논과 담수 토양에서 더 높은 함량을 나타내, 평균적으로 논토양과 오염 지역의 담수 토양에서 총 질소 함량이 높고 갯벌 토양에서 낮은 함량을 나타내었다.

총인 함량은 담수 토양과 유기농법에서 가장 높게 나타났 고, 오염 토양의 총 인 함량이 청정 토양보다 비교적 높게 나타 났으며, 총 인 함량도 질소 성분처럼 대부분 가을에 비교적 높게 나타나는 것을 확인할 수 있었다. 그리고 총 무기인의 함량도 총 인 함량과 비슷한 양상을 나타내 유기농법과 오염 된 토양에서, 그리고 가을 토양에서 비교적 높게 나타났다.
황산염 환원에 가장 큰 영향을 주는 것으로 알려진 황산염 농도를 조사한 결과 유기농법 토양이 평균 $3.36 \mathrm{mg} / \mathrm{kg}$, 농약 이 약 $3.32 \mathrm{mg} / \mathrm{kg}$, 청정 갯벌이 약 $34.03 \mathrm{mg} / \mathrm{kg}$, 오염 갯벌이 약 $41.01 \mathrm{mg} / \mathrm{kg}$, 청정 담수가 약 $1.59 \mathrm{mg} / \mathrm{kg}$, 오염 담수가 약 $2.50 \mathrm{mg} / \mathrm{kg}$ 로 나타나, 갯벌 토양의 황산염 함량이 가장 높았고, 담수의 함량이 가장 낮은 것으로 확인되었다. 그러나 계절변화에 따른 연관성은 찾아볼 수 없었다.

\section{황산염 환원세균(SRB)의 분포}

유기농 토양에서 초산을 이용하는 SRB가 $9.33 \times 10^{4}-2.4 \times 10^{5}$ $\mathrm{MPN} / \mathrm{g}$, 젖산을 이용하는 $\mathrm{SRB}$ 는 $9.32 \times 10^{3}-7.49 \times 10^{4} \mathrm{MPN} / \mathrm{g}$ 이 검출되어 유기농법 토양에 존재하는 평균 $\mathrm{SRB}$ 는 $1.03 \times 10^{5}$ $\mathrm{MPN} / \mathrm{g}$ 로 나타났고, 농약 토양에서 초산을 이용하는 SRB가 $3.61 \times 10^{4}-2.40 \times 10^{5} \mathrm{MPN} / \mathrm{g}$, 젖산을 이용하는 SRB는 $3.61 \times 10^{4}-$ $2.40 \times 10^{5} \mathrm{MPN} / \mathrm{g}$ 이 검출되어 농약 토양에 존재하는 평균 SRB 는 $1.27 \times 10^{5} \mathrm{MPN} / \mathrm{g}$ 으로 확인되었다. 그리고 청정 담수에서 초산을 이용하는 SRB가 $2.40 \times 10^{4}-3.61 \times 10^{4} \mathrm{MPN} / \mathrm{g}$, 젖산을 이 용하는 $\mathrm{SRB}$ 가 $9.31 \times 10^{3}-3.61 \times 10^{4} \mathrm{MPN} / \mathrm{g}$ 로 나타나 청정 담수 에 존재하는 평균 $\mathrm{SRB}$ 가 $2.30 \times 10^{4} \mathrm{MPN} / \mathrm{g}$ 로 확인되었고, 오 염 담수 토양에서 초산을 이용하는 SRB가 $2.40 \times 10^{4}-3.61 \times 10^{4}$ $\mathrm{MPN} / \mathrm{g}$, 젖산을 이용하는 $\mathrm{SRB}$ 가 $7.35 \times 10^{3}-2.40 \times 10^{4} \mathrm{MPN} / \mathrm{g}$ 
으로 나타나 오염 담수에 존재하는 평균 SRB가 $1.92 \times 10^{4}$ $\mathrm{MPN} / \mathrm{g}$ 로 확인되었다. 그러나 청정 갯벌과 오염 갯벌 토양의 초산과 젖산 이용 $\mathrm{SRB}$ 는 모두 $3.61 \times 10^{4} \mathrm{MPN} / \mathrm{g}$ 미만으로 나 타나 MPN으로 확인할 수 없었다.

따라서 토양 성분 분석에서는 갯벌 토양의 황산염 함량이 가장 높았지만, 실제 혐기 환경에 존재하는 초산과 젖산을 이 용하는 SRB는 논토양이 평균 $10^{5} \mathrm{MPN} / \mathrm{g}$, 담수가 평균 $10^{4}$ $\mathrm{MPN} / \mathrm{g}$ 그리고 갯벌에 그 이하의 균이 존재하고, 유기농 토양 보다 농약 토양이, 그리고 오염담수 토양보다 청정 담수 토양 의 SRB 분포가 약간 많음을 알 수 있었다. 그러나 계절적인 변화에 있어서는 큰 차이를 나타내지 않는 것으로 확인되었다 (Table 2).

\section{황화수소 생성}

가스 크로마토그라피를 이용하여 황화수소 생성 생성량을 특정한 결과 모든 토양 시료에서 배양 3 주째에 가장 높은 황화 수소 값을 나타내(data not shown), 배양 3 주째의 가스크로마 토그래피에서 검출되는 황화수소 값을 조사하여 황화수소 생 성량으로 비교하였다(Fig. 1).

유기농 토양의 초산과 젖산을 이용한 황화수소 생성량은 각각 $4.58 \mu \mathrm{mol} / \mathrm{g}$ 과 $18.65 \mu \mathrm{mol} / \mathrm{g}$, 전체 $23.23 \mu \mathrm{mol} / \mathrm{g}$ 을,

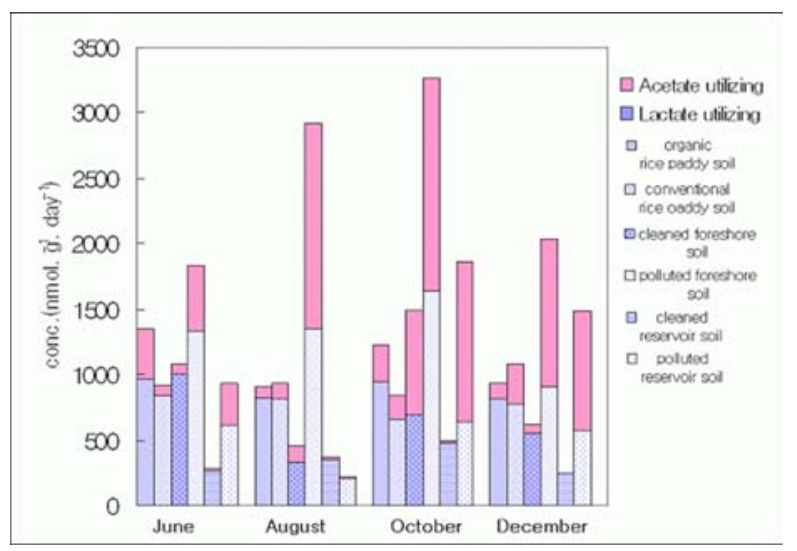

Fig. 1. Hydrogen sulfide production after cultivation for three weeks. Hydrogen sulfide production was detected in BCYT media with $20 \mathrm{mM}$ acetate and $20 \mathrm{mM}$ lactate as a carbon source, respectively.

관행 농법인 농약 토양의 초산과 젖산을 이용한 황화수소 생성 량은 각각 $3.61 \mu \mathrm{mol} / \mathrm{g}$ 과 $16.20 \mu \mathrm{mol} / \mathrm{g}$, 전체 $19.81 \mu \mathrm{mol} / \mathrm{g}$ 의 황화수소를 생성하였다. 그리고 청정갯벌 토양의 초산과 젖 산을 이용한 황화수소 생성량은 각각 $5.62 \mu \mathrm{mol} / \mathrm{g}$ 과 13.56 $\mu \mathrm{mol} / \mathrm{g}$ 으로, 전체 $19.19 \mu \mathrm{mol} / \mathrm{g}$ 을, 오염갯벌 토양은 각각

Table 2. MPN enumerations of sulfate reducing bacteria

\begin{tabular}{|c|c|c|c|}
\hline & & \multicolumn{2}{|c|}{ Enumeration (MPN/g) } \\
\hline & & Acetate utilizing & Lactate utilizing \\
\hline \multirow{4}{*}{ Organic rice paddy soil } & June & $2.40 \times 10^{5} \pm 1.476$ & $2.11 \times 10^{4} \pm 1.476$ \\
\hline & August & $9.33 \times 10^{4} \pm 0.7169$ & $7.49 \times 10^{4} \pm 0.5395$ \\
\hline & October & $<3.61 \times 10^{4} \pm 0.03024$ & $9.32 \times 10^{3} \pm 0.07372$ \\
\hline & November & $2.40 \times 10^{5} \pm 1.476$ & $4.27 \times 10^{4} \pm 0.02114$ \\
\hline \multirow{4}{*}{$\begin{array}{l}\text { Conventional rice paddy } \\
\text { soil }\end{array}$} & June & $1.50 \times 10^{5} \pm 1.095$ & $2.40 \times 10^{5} \pm 1.476$ \\
\hline & August & $3.61 \times 10^{4} \pm 0.03024$ & $3.61 \times 10^{4} \pm 0.03024$ \\
\hline & October & $<3.61 \times 10^{4} \pm 0.03024$ & $3.61 \times 10^{4} \pm 0.03024$ \\
\hline & November & $2.40 \times 10^{5} \pm 1.476$ & $1.50 \times 10^{5} \pm 1.095$ \\
\hline \multirow{4}{*}{ Cleaned foreshore soil } & June & $<3.61 \times 10^{4} \pm 0.03024$ & $<3.61 \times 10^{4} \pm 0.03024$ \\
\hline & August & $<3.61 \times 10^{4} \pm 0.03024$ & $<3.61 \times 10^{4} \pm 0.03024$ \\
\hline & October & $<3.61 \times 10^{4} \pm 0.03024$ & $<3.61 \times 10^{4} \pm 0.03024$ \\
\hline & December & $<3.61 \times 10^{4} \pm 0.03024$ & $<3.61 \times 10^{4} \pm 0.03024$ \\
\hline \multirow{4}{*}{ Polluted foreshore soil } & June & $<3.61 \times 10^{4} \pm 0.03024$ & $<3.61 \times 10^{4} \pm 0.03024$ \\
\hline & August & $<3.61 \times 10^{4} \pm 0.03024$ & $<3.61 \times 10^{4} \pm 0.03024$ \\
\hline & October & $<3.61 \times 10^{4} \pm 0.03024$ & $<3.61 \times 10^{4} \pm 0.03024$ \\
\hline & December & $<3.61 \times 10^{4} \pm 0.03024$ & $<3.61 \times 10^{4} \pm 0.03024$ \\
\hline \multirow{4}{*}{ Cleaned reservoir soil } & June & $2.40 \times 10^{4} \pm 0.1470$ & $9.31 \times 10^{3} \pm 0.07372$ \\
\hline & August & $3.61 \times 10^{4} \pm 0.03024$ & $3.61 \times 10^{4} \pm 0.03024$ \\
\hline & October & $<3.61 \times 10^{4} \pm 0.03024$ & $<3.61 \times 10^{4} \pm 0.03024$ \\
\hline & December & $<3.61 \times 10^{4} \pm 0.03024$ & $9.31 \times 10^{3} \pm 0.07372$ \\
\hline \multirow{4}{*}{ Polluted reservoir soil } & June & $2.40 \times 10^{4} \pm 0.1470$ & $2.40 \times 10^{4} \pm 0.1470$ \\
\hline & August & $3.61 \times 10^{4} \pm 0.03024$ & $7.35 \times 10^{3} \pm 0.05984$ \\
\hline & October & $<3.61 \times 10^{4} \pm 0.03024$ & $9.32 \times 10^{3} \pm 0.07372$ \\
\hline & December & $2.40 \times 10^{4} \pm 0.1470$ & $9.32 \times 10^{3} \pm 0.07372$ \\
\hline
\end{tabular}

All values are expressed in units of MPN per gram (wet weight) of soil.

* MPN 95\% confidence limits 
$25.24 \mu \mathrm{mol} / \mathrm{g}$ 과 $27.47 \mu \mathrm{mol} / \mathrm{g}$ 으로 전체 $52.71 \mu \mathrm{mol} / \mathrm{g}$ 의 황 화수소를 생성하였다. 또한 청정담수 토양은 초산과 젖산을 이용하여 각각 $0.31 \mu \mathrm{mol} / \mathrm{g}$ 과 $7.03 \mu \mathrm{mol} / \mathrm{g}$ 으로, 전체 7.35 $\mu \mathrm{mol} / \mathrm{g}$ 의 황화수소를 생성하였고, 오염담수 토양은 각각 $12.81 \mu \mathrm{mol} / \mathrm{g}$ 과 $10.74 \mu \mathrm{mol} / \mathrm{g}$ 으로, 전체 $23.55 \mu \mathrm{mol} / \mathrm{g}$ 의 황화 수소를 생성함을 확인하였다.

전체적으로 초산과 젖산을 이용한 황화수소 생성량의 평균 은 각각 $8.7 \mu \mathrm{mol} / \mathrm{g}$ 과 $15.6 \mu \mathrm{mol} / \mathrm{g}$ 으로 젖산을 이용할 때 황 화수소 생성량이 더 많음이 확인되어 초산을 이용하는 완전 산화균보다, 발효산물을 초산까지 산화하는 불완전 산화균의 활성이 우세한 것을 확인하였다.

\section{황산염 환원율}

${ }^{35} \mathrm{~S}_{-} \mathrm{SO}_{4}{ }^{2-}$ 를 이용하여 황산염 환원율을 조사한 결과(Fig. 2) 유기농 토양의 SRR은 평균 $117.72 \mathrm{nmol} / \mathrm{g} / \mathrm{day}$, 농약 토양은 평균 $122.45 \mathrm{nmol} / \mathrm{g} / \mathrm{day}$ 을 나타내었고, 계절적으로는, 유기 농과 농약 토양 모두 10 월 시료 토양이 각각 306.54 $\mathrm{nmol} / \mathrm{g} / \mathrm{day}$ 와 $239.52 \mathrm{nmol} / \mathrm{g} / \mathrm{day}$ 를 나타내 모든 종류의 토 양에서 가장 큰 값을 나타내었다.

그리고 갯벌토양은 청정 갯벌 SRR이 평균 $19.39 \mathrm{nmol} /$ $\mathrm{g} /$ day, 오염 갯벌은 평균 $27.36 \mathrm{nmol} / \mathrm{g} / \mathrm{day}$ 을 나타냈고, 청 정 갯벌 토양의 경우 10 월에 $239.52 \mathrm{nmol} / \mathrm{g} /$ day로 가장 큰 값을 보였지만, 오염 갯벌 토양의 경우에는 8월에 53.84 $\mathrm{nmol} / \mathrm{g} / \mathrm{day}$ 이 가장 높은 값으로 확인되었다. 담수토양의 경 우 청정 담수 토양의 SRR은 평균 $12.11 \mathrm{nmol} / \mathrm{g} / \mathrm{day}$, 오염 담수 토양은 평균 $26.88 \mathrm{nmol} / \mathrm{g} /$ day로 나타났고, 논보다는 낮았지만, 여름과 가을에는 갯벌토양과 비슷한 황산염 환원율

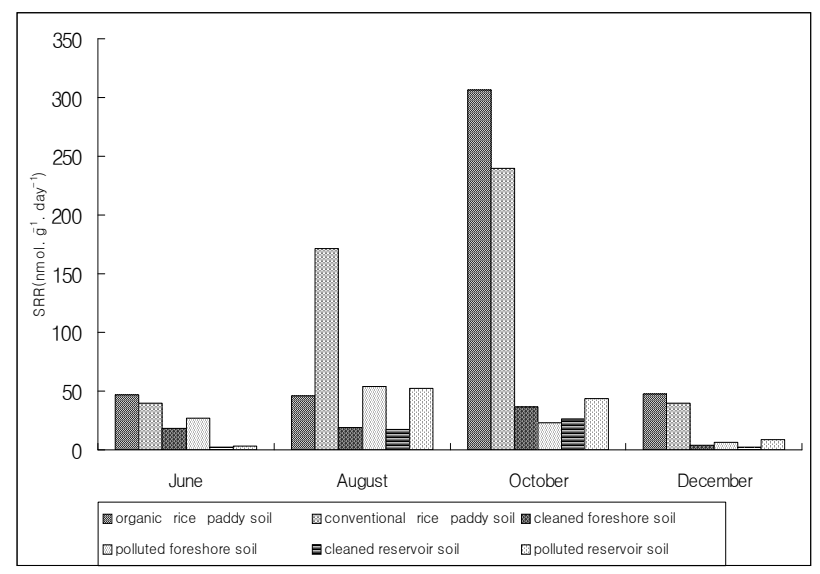

Fig. 2. Effect of changes in the season and the characteristics of soil on sulfate reduction rate. Sulfate reduction rate in $\mathrm{nmol} / \mathrm{g} /$ day was measured with ${ }^{35} \mathrm{~S}$-labelling. Soils were amended with $2 \mathrm{uCi}$ of carrier-free ${ }^{35} \mathrm{~S}_{-} \mathrm{SO}_{4}{ }^{-2}$ of wet soil and incubated in serum bottles for $48 \mathrm{~h}$ in dark. Sulfate reduction rate were determined by calculating the fraction of the sulfate pool which was reduced during the incubation.
을 나타내었다. 그리고 담수와 갯벌을 비교할 경우, 청정 담수 $(12.11 \mathrm{nmol} / \mathrm{g} /$ day $)$ 와 청정 갯벌 $(19.39 \mathrm{nmol} / \mathrm{g} /$ day $)$, 그리고 오염 담수(26.88 nmol/g/day)와 오염 갯벌(27.36 nmol/ $\mathrm{g} /$ day)은 서로 유사한 평균 수치를 보였고, 청정 담수 토양은 10 월에 $26.38 \mathrm{nmol} / \mathrm{g} /$ day로 가장 높고, 오염 담수 토양은 8월 에 $52.58 \mathrm{nmol} / \mathrm{g} / \mathrm{day}$ 로 가장 큰 높은 것으로 확인되어 일반적 으로 오염 담수지역이 청정담수 지역보다 SRR이 높은 것으로 확인되었다.

따라서 논토양의 SRR이 다른 지역 토양보다 높았고, 논토 양끼리의 비교에서는 큰 차이는 없었으나 농약 토양이 유기농 토양보다 약간 높게 나타났고, 담수 토양보다는 갯벌 토양에 서 더 높게, 그리고 청정 지역 토양보다는 오염 지역 토양의 SRR 값이 더 높은 것으로 확인되었다.

전체적으로는 농약 토양과 유기농 토양이 가장 큰 SRR 값 을 나타냈고, 그 다음으로 오염 갯벌 토양, 오염 담수 토양, 청정 갯벌 토양 그리고 청정 담수 토양의 순서로 나타났다.

\section{토양성분과 황산염 환원율의 상관관계}

본 실험에서 조사된 토양의 화학 성분들 중 특히 자연 생태 계의 균의 성장을 제한하는 요소인 질소와 인의 함량이 높아 정확한 상관관계를 추정하기 어려울 것으로 판단되었다. 그러 나 토양시료의 모든 성분과 SRR과의 유의성을 상관분석 프로 그램으로 통계처리를 해본 결과, 6월 시료에서는 SRR과 초산 산화균의 수와의 P값이 0.0536으로, 그리고 10월 시료에서는 $\mathrm{SRR}$ 과 암모니아 농도와의 $\mathrm{P}$ 값이 $0.0429, \mathrm{TP}$ 와의 $\mathrm{P}$ 값이 0.0552 로, 12 월 시료에서는 SRR과 암모니아 농도와의 P 값이 0.016으 로 그리고 초산 산화균수와의 P값이 0.0002로 나타나 유의성 이 있는 것으로 조사되었고, 일부 토양성분 특히, 질소와 인 그리고 토양에 존재하는 황산염 환원균의 수와 황산염 환원율 과는 유의성이 있음을 확인하였다. 또 일반적으로 토양의 황 산염 성분에 따라 황산염 환원과 그리고 황화수소 생성량이 영향을 받는 것으로 알려져 있으나, 본 실험 결과 토양 내 황산 염 농도보다는 다른 토양 성분들 즉, 오염 여부가 황산염 환원 과 황화수소 생성에 더욱 영향을 주는 것으로 확인되었다.

\section{고 찰}

본 실험은 담수와 해수의 청정지역과 오염지역의 토양 그리 고 유기농법과 관행농법을 사용한 논토양을 계절별로 채취하 여 각각의 혐기 환경에서의 토양성분, 황산염 환원세균 수, 황화수소 생성량과 황산염 환원율을 조사하여 혐기환경의 황 산염 환원에 대해 종합적으로 파악하고자 하였다. 본 실험에 서 각 토양의 수분 함량 분석 결과, 장마 후인 8월에 채취한 토양의 수분함량이 가장 높고 겨울로 갈수록 토양 수분 함량 이 전반적으로 낮아지는 경향을 보였으나, 청정지역 토양과 오염지역 토양의 수분함량의 차이는 나타나지 않았다. 토양의 
총 탄소 함량은 갯벌토양의 함량이 비교적 적고, 오염토양이 비교적 높은 것으로 나타났고 계절적인 큰 차이는 없었으나 일반적으로 가을철에 채취한 10 월 토양의 함량이 약간 높은 것으로 확인되었다. 총 유기탄소 함량 역시 갯벌의 함량이 낮 음을 알 수 있었으나, 계절과 오염에 따른 일반적인 경향을 파악할 수는 없었다. 그리고 농약 토양은 농약과 화학 비료를 사용하기 때문에 유기질 비료나 퇴비를 시비하는 유기농 토양 보다는 토양 내 유기물이나 생명체가 적다고 보고된 것과 같 이 농약 토양의 총 탄소 함량과 총 유기탄소 함량이 상대적으 로 낮은 것으로 나타났다[14]. 질소성분인 암모니아 함량은 계 절적으로 논토양은 겨울로 갈수록 암모니아가 축적되었고, 담 수와 갯벌 의 10 월 토양시료에서 가장 높은 함량을 나타냈다. 그리고 총 질소 함량은 논과 오염된 담수의 함량이 높고, 갯벌 의 함량이 낮은 것으로 나타났으나, 전체적으로 김해지구 초 지토양의 총 질소 함량과 비슷한 질소량을 갖고 있음을 확인 하였다. 토양의 총 인과 총 무기인의 함량은 담수토양과 유기 농의 함량이 가장 높고, 오염 지역의 함량이 청정지역보다 높 음을 알 수 있고, 총인 함량은 질소성분처럼 일반적으로 가을 에 비교적 높음을 확인할 수 있었다. 그리고 총 무기인의 함량 은 총 인과 비슷하게 유기농법과 오염된 환경에서, 계절적으 로는 가을에 비교적 높은 것으로 나타났다. 또 황산염 환원에 가장 큰 영향을 주는 것으로 알려진 황산염 농도를 조사한 결과, 갯벌의 황산염 함량이 가장 높고, 담수의 함량이 가장 낮은 것으로 나타났으며 계절에 따른 황산염 함량의 차이는 없는 것으로 나타났다. 이상의 결과 토양성분은 황산염 함량 을 제외하고 대부분의 토양 성분이 논토양에서 높게 나타났 고, 특히 관행농법인 농약을 사용한 논 보다 유기농법을 사용 한 논토양의 성분들이 비교적 높게 나타나, 일반적으로 유기 농법이 다양한 토양 성분을 많이 갖고 있어 작물의 생육에 유리함을 확인할 수 있었다. 그리고 오염된 담수와 갯벌을 비 교할 때 대부분의 토양성분들이 청정지역보다 오염지역에 많 이 함유되어 있어 주변 환경에 따라 토양 성분이 달라짐을 확인 할 수 있었다.

토양 성분과 황산염 환원균의 분포를 비교한 결과, 농약 토 양이 유기농 토양보다, 청정 담수토양이 오염 담수토양보다 황산염 환원균의 분포가 비교적 우세한 것으로 확인되어, 토 양 성분은 갯벌 토양의 황산염 함량이 가장 높지만, 토양 내 황산염 성분이 일정량 이상 존재하면 토양 내 황산염 함량보 다 다른 토양 성분들의 함량이 높은 토양에 황산염 환원균이 비교적 많이 분포하는 것을 확인하였다. 또 본 실험에서 확인 된 황산염 환원균의 수가, 논토양이 평균 $10^{5} \mathrm{MPN} / \mathrm{g}$, 담수가 평균 $10^{4} \mathrm{MPN} / \mathrm{g}$, 그리고 갯벌이 평균 $10^{3} \mathrm{MPN} / \mathrm{g}$ 이하의 균 이 존재하는 것으로 확인되어, 미국 플로리다 주 Everglades의 습지의 인산에 의해 오염된 지역에서 확인된 황산염 환원균 $1.5 \times 10^{6} \mathrm{MPN} / \mathrm{g}$ 과, 청정지역에 존재하는 황산염 환원균 $9.2 \times 10^{5} \mathrm{MPN} / \mathrm{g}$ [5], 독일의 Kattegat 해안 퇴적토의 균수 $10^{6}$
$\mathrm{MPN} / \mathrm{g}$ 보다 적게 나타났다[13]. 따라서 이처럼 황산염 함량 이 높은 갯벌 토양도 황산염 환원균의 수가 더 적게 검출된 것은 나트륨을 비롯한 해양 환경에 특이적으로 유지될 필요성 이 있는 여러 가지 무기염류의 양을 조절하거나 또는 복합적 인 전자공여체를 포함하여 기질로 사용된 전자공여체의 종류 와 농도에 따라서 황화수소 생성이나 황산염환원이 크게 영향 을 받는다는 보고처럼 $[15,16,17]$ 배지성분과 조건들에 따라 황 산염 환원균의 차이가 발생했기 때문이라 추정된다. 따라서 최근 사용되는 방사성동위원소 ${ }^{35} \mathrm{~S}_{-} \mathrm{SO}_{4}{ }^{-2}$ 를 이용한 T-MPN 방 법과 같은 개선된 MPN 방법을 이용하여 추가적인 연구가 진 행되어야 정확한 차이를 파악할 수 있을 것으로 생각된다 $[12,18,21]$.

황화수소 생성 실험에서 기질로 초산보다 젖산을 이용할 때 황화수소가 더 많이 생성하는 것으로 보아, 이들 토양에는 초산을 이용하는 완전 산화균보다 발효산물을 초산까지 산화 하는 불완전 산화균의 활성이 우세한 것으로 추정된다. 황산 염 환원 반응에서 젖산이 초산으로 불완전 산화할 경우의 표 준자유에너지의 변화 $\left(\mathrm{G}^{{ }^{\prime}}\right)$ 가 $-160.1 \mathrm{~kJ} / \mathrm{mol} \cdot \mathrm{sulfate}$, 초산이 이 산화탄소로 완전 산화할 경우 $\Delta \mathrm{G}^{0}$ 가 $-47.6 \mathrm{~kJ} / \mathrm{mol} \cdot$ sulfate이 므로 완전산화보다 불완전산화가 더 자발적인 반응이다 $[6,9,24]$. 따라서 본 연구에서 사용한 토양의 황화수소 생성량 을 볼 때 완전 산화균 보다 불완전 산화균의 활성이 우세하다 는 결과는 에너지 보존 측면과 일관성이 있는 것으로 보여진 다. 또 황화수소 생성량은 오염된 갯벌이 $52.71 \mu \mathrm{mol} / \mathrm{g}$ 으로 가장 높고, 논과 오염된 담수, 청정 갯벌 토양이 약 19.19-23.55 $\mu \mathrm{mol} / \mathrm{g}$ 로 비슷하고, 청정담수가 $7.35 \mu \mathrm{mol} / \mathrm{g}$ 로 나타나, 황화 수소 생성은 담수보다는 황산염 성분이 높은 갯벌이, 청정지 역 보다는 오염된 환경에서 많이 생성하는 것을 확인할 수 있었다. 그리고 계절별로는 토양 내 영양소가 농축 되는 10 월 토양에서 황화수소 생성이 가장 높아, 황화수소 생성은 온도 보다는 영양소 성분에 의해 영향 받음을 알 수 있었다.

황산염 환원율은 황산염 농도가 높은 갯벌토양의 황산염 환원율이 높게 나타날 것이라는 예상과는 달리 논토양이 가장 높고, 담수토양이 가장 낮게, 그리고 오염된 토양이 청정한 토양보다 황산염 환원율이 높은 것으로 나타났다. 또 계절적 으로는 논토양은 일반적으로 토양성분이 높게 나타나는 가을 에 가장 높았고, 갯벌과 담수는 기온이 높은 8월 시료와 토양 성분들이 농축된 10 월 시료에서 높게 나타나 황산염 환원율도 황화수소 생성과 같이 토양의 영양소에 영향을 받고, 또한 온 도에 의해서도 영향을 받는 것을 알 수 있었다. 따라서 황산염 환원은 토양성분과 온도 등의 복합적 요인과 관계가 있을 것 으로 생각된다. 일반적으로 해수에는 적당량 황산염 농도가 존재하기 때문에 해수 전체 탄소 순환의 상당부분에 황산염 환원 관여하는 것으로 알려져 있고[10,22], 이에 대한 많은 연 구가 이루어졌으나 [1,3] 담수 환경에서의 황산염 환원 연구는 거의 진행되지 않았다. 그러나 최근 몇 년 동안의 연구 결과는 
담수도 해수만큼이나 높다는 사실이 알려지고 있는데 이는 논농사 지역의 낮은 황산염 농도를 함유한 토양에서도 황산염 환원세균이 잘 적응할 수 있다는 잠재적인 가능성을 시사해주 는 증거라고 생각되며 본 연구의 결과와 어느 정도 유사성이 있다고 여겨진다[4,11]. 특히, 농사 지역과 담수 지역 모두 황산 염 농도가 갯벌 토양보다 현저히 낮은 편이었는데도 황산염 환원율은 논토양이 담수 토양보다 높게 나타난 것은 토양 내 함유된 성분들과 벼 뿌리주변에 존재하는 미생물들 간의 유기 적인 상호작용이 황산염 환원율과도 관련이 있을 것으로 추측 되므로[25], 추후 식생과 비식생의 차이에 의한 비교 연구가 필요할 것으로 판단된다.

\section{감사의 글}

이 논문은 교육과학기술부에서 주관하는 대형연구시설 공 동이용 활성화 분야(하나로) 연구지원 사업(M2051100006005B0200-0600) 지원을 받아 연구되었습니다.

\section{References}

1. Bak, F. and N. Pfennig. 1991. Microbial sulfate reduction in littoral sediment of Lake Constance. FEMS Microbiology Ecology 85, 31-42.

2. Balch, W. E., G. E. Fox, L. J. Magrum, C. R. Woese, and R. S. Wolfe. 1979. Methanogens: reevaluation of a unique biological group. Microbiol. Rev. 43, 260-296.

3. Canfield, D. E. 1989. Sulfate reduction and oxic respiration in marine sediments: Implications for organic carbon preservation in anoxic environments. Deep-Sea Res. 36, 121-138.

4. Cappenberg, T. E. 1974. Interrelations between sulfate-reducing and methane-producing bacteria in bottom deposits of a fresh-water lake. Antonie van Leeuwenhoek 40, 285-295.

5. Castro, H. F. 2003. Microbial ecology of anaerobic terminal carbon mineralization in Everglades soils, with emphasis on sulfate reducing prokaryotic assemblages. Ph. D. Thesis. 27-37.

6. Detmers, J., V. Brüchert, K. S. Habicht, and J. Kuever. 2001. Diversity of Sulfur Isotope Fractionations by Sulfate Reducing Prokaryotes. Appl. Environ. Microbiol. 67, 888-894.

7. Douglas, G. C. and R. P. Kiene. 1988. Comparison of microbial dynamics in marine and freshwater sediments: Contrasts in Anaerobic Carbon metabolism Limnology and Oceanography 33, 725-749.

8. Fossing, H. and B. B. Jorgensen. 1989. Measurement of bacterial sulfate reduction in sediments: Evaluation of a single-step chromium reduction method. Biogeochemistry 8, 205-222.

9. Hansen, T. A. 1994. Metabolism of sulfate-reducing bacteria. Antonie van Leeuwenhoek 66, 165-185.

10. Howarth, R. W. 1984. The ecological significance of sulfur in the energy dynamics of salt marsh and coastal marine sediments. Biogeochemistry 1, 5-27.

11. Ingvorsen, K., J. G. Zeikus, and T. D. Brock. 1981. Dynamics of Bacterial Sulfate Reduction in a Eutrophic Lake. Appl. Environ. Microbiol. 42, 1029-1036.

12. Jain, D. K. 1995. Evaluation of the semisolid Postgate"s B medium for enumerating sulfate-reducing bacteria. $J$. Microbiol. Methods 22, 27-38.

13. Jørgensen, B. B. and F. Bak. 1991. Pathways and microbiology of thiosulfate transformations and sulfate reduction in a marine sediment (Kattegat, Denmark). Appl. Environ. Microbiol. Mar. 57, 847-856.

14. Kim H. S., J. S. Cho, and K. R. Park. 2009. Methane production and T-RFLP patterns of methanogenic bacteria dependent on agricultural methods. Korean J. of Microbiol. 45, $17-25$.

15. Ronald, S. 1982. Oremland and sandra polcin methanogenesis and sulfate reduction: competitive and noncompetitive substrates in estuary sediments. Appl. Envir. Microbiol. 44. 1270-1276.

16. Smith, R. L. and M. J. Klug. 1981. Electron donors utilized by sulfate reducing bacteria in eutrophic lake sediments. Appl. Environ. Microbiol. 42, 116-121.

17. Sorensen, J., D. Christensen, and B. B. Jørgensen. 1981. Volatile fatty acids and hydrogen as substrates for sulfate reducing bacteria in anaerobic marine sediment. Appl. Environ. Microbiol. 42, 5-11.

18. Tanner, R. S. 1989. Monitoring sulfate-reducing bacteria: Comparison of enumeration media. J. Microbiol. Methods 10, 83-90.

19. Touzel, J. P. and G. Albagnac. 1983. Isolation and characterization of Methanococcus Mazei strain MC3. FEMS Microbial. Lett. 16, 241-245.

20. Ulrich, G. A., L. R. Krumholz, and J. M. Suflita. 1997. A rapid and simple method for estimating sulfate reduction. Appl. Environ. Microbiol. 63, 1627-1630.

21. Vester, F. and K. Ingvorsen. 1998. Improved most probable number method to detect sulfate-reducing bacteria with natural media and a radiotracer. Appl. Environ. Microbiol. 64, 1700-1707.

22. Ward, D. M. and M. R. Winefry. 1985. Interactions between methanogenic and sulphate reducing bacteria in sediments. Adv. Aquat. Microbiol. 3, 141-179.

23. Westermann, P. 1993. Wetland and swamp microbiology. pp. 215-238, In Ford, T. E. (ed.), Aquatic microbiology. Blackwell Sci. Publ., Cambridge, MA.

24. Widdel, F. and T. A. Hansen. 1992. The dissimilatory sulfate-and sulfur reducing bacteria, pp. 583-624, In Balows, A., H. G. Truper, M. Dworkin, W. Harder, and K. H. Schleifer (eds.), The prokaryotes (2nd ed.), Vol. I, Springer, New York, N.Y.

25. Wind, T. and R. Conrad. 1997. Localization of sulfate reduction in planted and unplanted rice field soil. Biogeochemistry 37, 253-278. 


\section{초록 : 논과 갯벌과 저수지 토양의 황산염 환원}

\section{김민정 · 박경량*}

(한남대학교 생명나노과학대학 생명공학과)

유기농법과 관행 농법토양, 청정 갯벌과 오염 갯벌토양 그리고 청정 담수와 오염 담수 토양을 이용하여 계절의 변화에 따라 ${ }^{35} \mathrm{SO}_{4}{ }^{-2}$ 을 이용한 황산염 환원율, 가스크로마토그래피를 이용한 황화수소 생성량, 최적확수 시험법을 이용한 황산염 환원세균의 분포, 공정시험법을 이용한 수분, 암모니아, 총 질소, 총 유기탄소, 총 탄소, 총 무기인, 총 인, 황산염 농도의 토양 성분조사를 실시하였다. 그 결과 황산염 환원율은 황산염의 농도보다 황산염 환원세균 의 군집크기와 질소와 인과 같은 토양 성분과 서로 밀접한 관련이 있는 것으로 확인되었다. 그리고 황화수소 생 성량은 10 월 토양에서 가장 높게 나타났으나, 담수 토양 보다는 높은 황산염 농도를 함유한 갯벌 토양에서 더 높게 나타났고, 청정 지역보다는 오염 지역 토양에서 높은 값을 나타냈다. 따라서 혐기환경의 황산염 환원율과 황화수소 생성량은 황산염 환원세균의 군집과 토양 내 여러 가지 성분 그리고 온도에 의해 영향 받는 것을 확인 하였다. 